\title{
Uricska Erna
}

\section{\#instapolice\#thinbluelinefamily \\ Online reputációmenedzsment a police_hu Instagram-profilján}

\author{
\#instapolice\#thinbluelinefamily \\ Online reputation management on the Instagram profile of police_hu
}

„A bizalom gyalog jön és lóháton távozik.”

(Kozáry Andrea)

\begin{abstract}
Absztrakt
Az elmúlt évtizedekben számos rendészeti kommunikációs szakember írt arról, hogy a lakosság és a rendőrség viszonyát elsősorban a kommunikáció minősége határozza meg. A Google felmérése szerint 2001-ben a szervezetek és a vállalatok vezetőinek és munkatársainak $22 \%$-a keresett rá a világhálón a saját szervezetére vagy vállalatára. Ez az arány 2013-ra 56\%-ra emelkedett, így feltételezhetjük, hogy ez 2021-ben még magasabb lesz. Nem csoda tehát, ha a digitális korban egy új koncepció, egy elengedhetetlenül fontos szakmai, egyúttal társadalmi készség jelenik meg: az online reputációmenedzsment. Ez napjainkban magánszemélyekre, cégekre és szervezetekre is érvényes, így a rendőrségre is, hiszen nem közömbös, hogy az adott egység milyen digitális lábnyomot hagy maga után az online térben. A reputációmenedzsment célja az, hogy megismertesse és pozitívan befolyásolja az adott szervezetről alkotott képet. A rendészeti közösségi oldalak használata a rendőrség mint szolgáltató szervezet, és a lakosság tagjai között valósul meg, ahol lehetőség van a valós idejű információmegosztásra és -szerzésre. Így a rendészeti közösségi oldalak a tájékoztatás eszközeként központi jelentőségűvé váltak nemcsak az állampolgárok, hanem az újságírók és a sajtóreferensek számára is. A rendőrök azonban nemcsak tájékoztatásra törekszenek ezeken a felületeken, hanem megpróbálják együttmüködésre bírni a civileket. Érezhető az a változás, hogy lecsökkent a szöveges tartalom jelentősége, ezzel párhuzamosan pedig egyre erőteljesebb a vizuális
\end{abstract}


megjelenítés. Elmondható, hogy a lakosság a szervezet részéről a világhálón nem feltétlenül mennyiségi, hanem minőségi jelenlétet vár el. Éppen ezért nem mindig a kedvelések, hanem a hozzászólások száma és minősége árulkodik arról, hogy a felhasználók mennyire azonosultak az adott témával és annak képi világával. Jelen tanulmány a magyar rendőrség (police_hu) Instagram-oldalának bejegyzéseit vizsgálja annak kezdetétől, 2019. július 3-tól, 2020. július 3 -ig. A kutatás az egyéves időtartam tíz legnépszerúbb és legtöbb kommentet kapott bejegyzéseit jellemzi, a diskurzuselemzés módszerét alkalmazva. Ennek eredményeképpen elmondható, hogy a magyar rendőrség az Instagram-oldalán zajló folyamattal egyfajta márkaépítést valósít meg, mely méltán tekinthető a rendőrségi kommunikáció pozitív példájának, ahol jól megfigyelhetők a rendészeti digilektus ${ }^{1}$ jellegzetességei.

Kulcsszavak: közösségi média, Instagram, magyar rendőrség, online reputáció, rendészeti digilektus

\begin{abstract}
In recent decades several experts have argued that the relationship between the police and the community is particularly determined by the quality of communication. The findings of studies carried out by Google show that 22 percent of the organisations and companies searched for themselves online in 2001. The figure was $56 \%$ in 2013 , so it can be assumed that this proportion will be even higher in 2021. Thus, it is no wonder that in the digital age a new concept, an essential professional and social skill is emerging - online reputation management. It is not indifferent what type of digital footprint has been left behind in the online space, and it is not only true for citizens, but also for companies and organisations, and for the police as well, nowadays. The aim of reputation management is to make the overall picture of the organisation well-known and influence it positively. The use of policing social networking sites is applied between the police as a service provider organisation and the members of the community, and there is a chance for sharing and getting real time information. As a result, policing social networking sites bear utmost importance for citizens, journalists and press officers as well. Police officers not only seek to share information but persuade the citizens to cooperate. The limited importance
\end{abstract}

1 A rendészeti digilektus a szerző önálló fogalma, hivatkozva Veszelszkire (2017ab), akinek a digilektus szó önálló szóalkotása. A rendészeti digilektus az online térben, egyes rendészeti közösségi oldalakon használt nyelvváltozat (Uricska, 2020b). 
of textual content can be seen and in parallel, the visual content has become more important. It can be stated that the members of community do not expect a quantitative, but a qualitative presence. Thus, it is the number and quality of comments that reveal how deeply users have been involved in the topic and its imagery content. This study deals with the Instagram profile of the Hungarian Police (police_hu) between July 3, 2019 and July 3, 2020. Applying the method of discourse analysis, the research characterises the most popular and most commented entries during the one-year period. As a result, it can be said that the process taking place on the Instagram of the Hungarian Police implements a kind of brand building, which can be considered as a positive example of police communication, while the characteristics of policing digilect can be well observed and analysed.

Keywords: social media, Instagram, Hungarian Police, online reputation, policing digilect

\section{Elméleti háttér és előzmények}

A közösségimédia-oldalakat mint kommunikációs felületeket széles körben alkalmazzák az élet különbözö területein, így például a kereskedelem, a turizmus és az oktatás területén is (Heravi \& Harrowe, 2016). Az emberek naponta több órát töltenek azzal, hogy ezeket az alkalmazásokat használják, amikor interakcióba lépnek egymással, és amikor a legfrissebb hírek után böngésznek. Ezek a felületek alapvető fontosságúak, hiszen lehetőség van a valós idejű információmegosztásra és -szerzésre, melynek eredményeképpen központi jelentőségüvé váltak nemcsak a lakosság tájékoztatásában, hanem az újságírók és a sajtóreferensek számára is.

A közösségi oldalak szerepe, lehetőségei, azok jótékony és káros hatásainak vizsgálata céljából számos nemzetközi tanulmány és kutatás látott napvilágot az elmúlt években (Boyd \& Ellison, 2007; Hall, 2019), valamint Magyarországon is hasonló folyamatnak lehetünk tanúi, hiszen az élet több területén (például marketing, oktatás) is alkalmazzák ezeket az oldalakat (Vályi, 2007; Barnucz \& Uricska, 2020a). Az Egyesült Államok számos tagállamában, Finnországban, de akár a szomszédos Szlovákiában is (Uricska, 2020a) a rendészeti egységek napi szinten és tudatosan használják ezeket az oldalakat a lakosság tagjainak eléréséhez. A magyar rendészeti szervezetek még nem teljes mértékben aknázták ki ezeknek az oldalaknak a lehetőségeit, azonban a jelenlegi eredmények bizakodásra adnak okot (Uricska, 2020b). 
Tény, hogy e kérdéskörben Magyarországon is valódi paradigmaváltásra van szükség, azonban a szervezet kommunikációs stratégiájának folyamatban lévő reformja nem egyetlen kampányból, nem egyetlen döntésből és akcióból áll, hanem fokozatos és folyamatos változtatások szükségesek (Farkas, Krauzer \& Sallai, 2020ab). Ennek következtében a rendőrség a folyton változó társadalom tagjainak rendőrséggel szembeni elvárásaihoz igazodhat (Molnár, 2018; Farkas \& Horváth, 2020). A rendőrségi reform alapkérdése az egyén és a hatalom kapcsolata is egyben, és ezzel összefüggésben a két fél kommunikációjának minősége meghatározó, ahogy azt a hazai rendészeti szakember (Less, 2015), valamint a hazai és nemzetközi rendészeti kommunikációs szakemberek is részletesen leírták (Molnár, 2018; Colbran, 2020).

Az információs társadalom megjelenésével a digitális átalakulás nem választás kérdése, hanem egy elkerülhetetlen jelenség, amelyre mindenkinek fel kell készülnie. Ezt igazolja az a kormányhatározat ${ }^{2}$, amelynek jogalkotói szándékát az a gondolati előrelátás tükrözi, mely szerint 20 . századi tudással senki nem lehet versenyképes a 21. században. A beavatkozási, átalakítási területek már nemcsak a köznevelés, a felsőoktatás és a felnőttkori tanulás, ezen belül a rendészeti képzés (Borszéki, 2019) területein jelentkeznek, hanem ezzel párhuzamosan a munka világát is áthatják (Pirzada \& Khan, 2013; Barnucz \& Uricska, 2020b). A digitális kompetenciák fontosságát, szükségszerüségét támasztja alá az a váratlan esemény is, hogy a tanulmány készítésének időpontjában, 2021 márciusában Magyarországon nagyjából egy éve van hivatalosan is jelen a koronavírus, illetve a járványhelyzet miatt a köz- és felsőoktatásban tanulók az otthonaikban tanulnak, és a felnőtt munkavállalók is otthoni munkavégzés rendjében, digitális úton látják el feladataikat.

Valószínűleg nem túlzás azt állítani, hogy a magyar rendőrség - összehasonlítva a külföldi országok rendészeti szervezeteivel - viszonylag későn jelent meg a közösségi média platformokon: 2016 óta van a rendörségnek Twitter-fiókja, 2019. július 3-án a police hu oldal is elindult az Instagram alkalmazáson, és 2020 óta Facebook-oldallal is rendelkezik. A közösségi oldalakon való későbbi megjelenéssel indokolható az, hogy a rendőrség még nem aknázta ki teljes mértékben az említett fórumok lehetőségeit.

A rendőrség személyi állományának kommunikációját a rendőrség szolgálati szabályzatáról szóló 30/2011. (IX. 22.) BM rendelet szabályozza. A norma 73. pontja „A rendőr nyilvános szereplése” rögzíti a rendőr nyilvános szereplésének kereteit. Ez olyan jogszabályi rendelkező rész, amelynek megsértése

2 1536/2016. (X. 13.) Korm. határozat a köznevelési, a szakképzési, a felsőoktatási és a felnőttképzési rendszer digitális átalakításáról és Magyarország Digitális Oktatási Stratégiájáról. 
túlmutathat a fegyelemsértésen. A közösségi oldalakon történő szereplésre vonatkozó egyéb közjogi szervezetszabályozó eszköz 2019-ben született meg a közösségi média és az internetes felületek rendőrségi használatáról szóló 41/2019. (XII. 13.) ORFK utasítással. A norma 37. pontja alapján ,, a Rendörség személyi állományába tartozó munkavállaló a közösségi médiában magánszemélyként történö véleménynyilvánitáskor köteles tiszteletben tartani a Rendörség jó hírnevét és szervezeti érdekét." Azonban az utasítás hatályba lépését megelőzően már bevett gyakorlattá vált, hogy nyilvánosan, következmények nélkül lehet a szervezetbe vetett bizalmat aláásni, hiszen nem létezett még erre vonatkozóan hivatalos állásfoglalás. A jogszabályi háttér kiegészítése az egyéb szervezetszabályzó jogi eszközzel elengedhetetlenül szükséges volt, hiszen egyáltalán nem mindegy, hogy milyen információk látnak napvilágot az online térben magánszemélyekről, szervezetekről, és azok milyen hatással vannak a digitális identitásra (Beduschi, 2019).

A Google felmérése (URL1) szerint már 2001-ben is az emberek 22\%-a keresett rá a saját szervezetére, amelyet a szakirodalomban ego-szörfözésnek vagy hiúsági keresésnek neveznek (Yonetani, Kitani \& Sato, 2018). A személyes vagy céges online jelenlét ellenőrzése 2013-ban 56\% volt, és ez alapján feltételezhetjük, hogy ez az adat 2021-ben még magasabb lesz. Napjainkban az üzleti lehetőségek feltérképezése, az üzleti kapcsolatok kiépítése és megszilárdítása, de akár álláskeresés során is előfordul - akár a munkavállalói, akár a munkaadói oldalról -, hogy több online felületen is ellenőrzik egy magánszemély, egy szervezet vagy egy cég digitális lábnyomát (Micheli, Lutz \& Büchi, 2018).

Az online jelenlét minőségének köszönhetően egyre nagyobb az igény az online reputációmenedzsmentre, ahol magánszemélyek, közéleti személyiségek vagy akár cégek is kontrollálni szeretnék a saját digitális lábnyomukat. Bár ez még egy viszonylag fiatal üzletág és kutatási terület, de egyre több cég és szakértő (McDermott, 2018; Micheli et al., 2018) foglalkozik ezzel a területtel. Az online reputációmenedzsment az internet, a közösségi média fokozódó és folyamatos térhódításával vált ki a Public Relations (továbbiakban: PR) területéböl a 2000-es évek tájékán. Az online folyamat célja egyrészt a vásárlókkal, az érdeklődőkkel való folyamatos kapcsolattartás, kommunikáció vagy kommunikációs stratégia kialakítása (Stenger, 2014); másrészt az előzőekben is említett digitális identitás befolyásolása. Molnár (2018) megfogalmazása szerint „a stratégia egy átfogó koncepció, amely távlati célokat, cselekvési sávokat jelöl $k i$, valamint olyan feladatokat fogalmaz meg, amelyek hatásos eszközt jelenthetnek a szervezeti célok eléréséhez" (Molnár, 2018). Ennek tükrében a kommunikációs stratégia tartalma általában a vezető vagy a menedzsment akarataként, írásban jelenik meg, attól függően, hogy hosszú, közép- vagy rövid távú 
koncepciót fogalmaz-e meg (Molnár, 2018). Ezen stratégia célja akár az egyéni hírnév, akár egy szervezet digitális jó hírnevének elősegítése is lehet.

Az online reputációmenedzsmentnek preventív, stabilizáló, de akár helyreállító szerepet is tulajdoníthatunk, amely föleg pozitív információk gyártásáról, valamint ezeknek a megfelelő csatornákon történő terjesztéséről szól. Általánosságban az online PR során olyan információk, cikkek jelennek meg szervezetekröl, magánszemélyről, amelyek elönyös színben próbálják meg feltüntetni az adott szereplőt. Bár ezek rövidtávú hatása ugyan jellemzően pozitív, a hosszú távú hatásukat nehéz mérni. A legjellemzőbb hátrányuk, hogy egy-egy ilyen megjelenés több százezer vagy akár millió forintos nagyságrendủ anyagi vonzattal jár. Ha az adott cikk életciklusa lejár, tény, hogy kevesen fogják azt megtalálni és olvasni. Ebbe a folyamatba robbantak be, és forgatták fel a média világát a közösségi oldalak, ahol a szervezet közvetlenül képviselteti magát, és kommunikációs szakemberekkel próbálják pozitív irányba befolyásolni az online jelenlétet (Markos-Kujbus \& Gáti, 2012).

A reputációmenedzsment célja nem pusztán a marketing és az online PR megvalósítása, és korántsem egy egyszeri tevékenység. Ennél többröl van szó. A rendészeti közösségi oldalak használatának rövid távú eredménye lehet, hogy a rendőrség szolgáltató jellege az említett kommunikációs csatornákon egyre inkább kezd elötérbe kerülni. Legyen szó akár a Facebook, akár az Instagram vagy a Twitter felületéről, a szervezet tagjai közvetett módon kommunikálnak a lakosság tagjaival. Persze nem minden tagja. Az is rendkívül fontos, hogy azok, akik egy-egy ilyen felületet müködtetnek, a tevékenységre felkészültek legyenek. A képzés e téren is mindenekelőtt való, ám Molnár és Tamási 2019es tanulmányának végén megállapítja: „A magyar rendör kitünö elméleti képzést kap a középiskolától az egyetemig. Tisztában van a jogszabályokkal, jobb esetben a szakma mesterfogásaival, de sokszor a legjobb felkészültség is csödöt mondhat az elhibázott kommunikáció miatt” (Molnár \& Tamási, 2019).

Az Instagramon látványos az a változás, hogy érezhetően lecsökkent a szöveges tartalom jelentősége, míg egyre erőteljesebb a vizuális megjelenítés. Ez azonban nem véletlen, hiszen a kommunikációs közeg hatást gyakorol a közvetítendő tartalom lényegére is (Benczik, 2010). Márpedig a közösségi oldalakon a vizualitásé a föszerep.

Egy felület elnevezése sem lehet véletlen. Az Instagram két angol eredetü szóból, az instant camera és telegram szavakból szóösszerántással képzett szó, ezért vélhetően a névnek az üzenete hatással van arra a stílusra és tartalomra is, ami erre az oldalra felkerül. Ebből kifolyólag a képi és a szöveges elem együtt él. Népszerúek azok a bejegyzések, amelyek mellé videót és fényképet is megoszt a felhasználó. Sőt, azok a videók, amelyekben híres ember (URL2), 
„celeb” (például színész [URL3], énekes, pap [URL4]) adja a nevét a rendőrség munkájához, láthatóan népszerúbbek, hasonlóan azokhoz a képekhez, amelyek csaknem müvészinek tekinthetők, és a nyílt, egyértelmü tartalom mellett látens utalást tartalmaznak, esetleg a felhasználó maga is történetet szőhet a kép köré (lásd a kutatás eredményei). Elmondható, hogy a lakosság a szervezet részéről a világhálón nem feltétlenül mennyiségi, hanem minőségi jelenlétet vár el (Uricska, 2020b).

\section{A kutatás kérdései és hipotézisei}

Jelen tanulmány a magyar rendőrség Instagram-profilja első évének tevékenységeit hivatott bemutatni, amelyet méltán nevezhetünk brandépítésnek, és a rendőrségi kommunikáció pozitív példájának. A portál 2019. július 3-án kezdte meg müködését, és az első egy év alatt vizuális és verbális tartalmában egyaránt színvonalas felületet hozott létre, amit még csak kevés közigazgatási szervezet tud prezentálni 2021 elején. Még Magyarország Kormánya is több mint egy ével később, 2020. szeptember 17-én jelent meg az Instagramon (URL5). A felületek létrehozása során több tényező harmonizálását kell szem előtt tartani, annak érdekében, hogy a megosztott információ eljusson az érdeklődőkhöz.

Egy adott szervezet vagy személy jó hírnevének, reputációjának növelésére különböző módszerek léteznek. Az egyik a megfelelő kommunikáció, legyen az offline vagy online rendészeti kommunikáció. A digitális rendészeti kommunikáció jelentőségének megfigyelésére az alábbi kutatási kérdéseket vizsgáltuk:

1.) Van-e változás a rendőrségről kialakult kép/imázs tekintetében a korábbiakkal ellentétben (rendőrviccek, rendőri visszaélésekről szóló hírek)?

2.) Ha igen, milyen irányú változás figyelhető meg a rendőrségről kialakult kép vonatkozásában?

3.) Ha igen, minek hatására változott a rendőrségről kialakult kép a korábbiakhoz képest?

A kutatási kérdésekhez rendelve három feltételezés tesztelésére vállalkoztunk, amelyeket Veszelszki (2017ab) és Uricska (2020ab) kutatásai alapján fogalmaztunk meg:

1.) A police_hu oldalon létrehozott rendészeti digitális kommunikációs tartalmaknak megvan a lehetőségük arra, hogy átrendezzék a rendőrség, az egyén és a társadalom viszonyait és kapcsolatrendszerét. 
2.) Az azonnali válaszadás lehetőségeit kihasználva a magyar rendőrség a lakosság közvetlen elérésére, bizalomépítésre, partneri viszony kialakítására törekszik, ezáltal pozitív irányban változott a társadalom tagjainak a szervezetről alkotott megítélése, amely a visszajelzések gyakoriságában és tartalmi elemeiben (komment, emotikon) is megmutatkozik.

3.) A magyar rendőrségnek a közösségi oldalakon a vizuális és verbális tartalmak, azaz a rendészeti digitális diskurzus minőségével, valamint a közvetlenebb nyelvhasználati stílusréteg, azaz a rendészeti digilektus alkalmazásával sikerült pozitív irányba változtatni a szervezetről kialakult képet.

\section{Mintaválasztás - A kutatás bemutatása}

A vizsgálat során a magyar rendőrség Instagram-oldalán található police_hu első éve (2019. július 3. - 2020. július 3.) alatt létrehozott tíz legnépszerübb posztot vizsgáltuk a diskurzuselemzés módszerével. „, A diskurzuselemzés lényege, hogy valójában a nyelv révén tudjuk megteremteni és kifejezni szubjektivitásunkat, általa vagyunk képesek társadalmi tevékenységeket kifejteni, hatalmi relációkat kialakitani" (Carver, 2004). A kutatás alapsokasága $\mathrm{N}=695$ bejegyzés. A vizsgálat ideje alatt (2019. július - 2020. július) a rendészeti közösségi oldal aktivitását, hirdetéseit és kapcsolattartási hajlandóságát vizsgáltuk a bejegyzések által. A vizsgált minta $\mathrm{n}=10$, ahol az elemzési egységek az alábbiak: a bejegyzések témája, a kedvelések száma és a hozzájuk kapcsolódó interaktivitás, a kommentek száma és minősége. A vizsgált időszakban a lakosság tagjainak együttmüködési, a párbeszédekben való részvételi hajlandósága (kommentek száma) alapján a tíz legnépszerübb poszt tartalmi szempontból 3+1 téma köré csoportosítható: 1) a kiskutyák névadása; 2) rendőrlányok, azaz a nőiesség és a hivatás elismerése; 3 ) a rendőrségi szóvivő szereplésével készült fotók, és végül 4) a rendőrautók. A portál elindulását követően több hónapra volt szükség a követők számának növelésére, akik kedvelés vagy komment formájában reagálnak a bejegyzésekre. Az első átütő sikerü bejegyzés 2019 októberében keletkezett, amikor is kutyakölyköknek kellett nevet adni. Habár látszólag a témának a rendőri hivatáshoz nincs köze (természetesen van, hiszen a kölyökkutyákból szagló-, illetve keresőkutyák válnak), mégis rekordszámú komment érkezett a bejegyzésre. Érdekesség, hogy a vizsgált időtartam alatt a tíz legnépszerübb bejegyzés közül öt a koronavírus-járvány első hullámának pár hónapjára (2020. március - 2020. június) datálható, aminek az lehet az oka, hogy a felhasználók internetezési, böngészési szokásai megváltoztak, és több időt fordítottak a közösségi média oldalainak olvasására (Aristovnik, Keržič, Ravšelj, Tomaževič \& Umek, 2020). 


\section{A kutatás eredményei}

\section{Névadás kutyakölyköknek}

A bejegyzés létrehozásának dátuma 2019. október 29. (1. számú ábra). A bejegyzést 3600 fö kedvelte, de ami ennél is beszédesebb, az a kommentek száma. A call-to-action ${ }^{3}$ bejegyzéshez - amit leginkább „cselekvésre való felhívásnak”, esetleg „felhívás keringőre” szószerkezeteknek fordíthatnánk - 930 komment érkezett. A cselekvésre való felhívásnak rövidnek, világosnak és meggyőzőnek kell lennie. A kiskutyáknak való névadás jó gyakorlatként is megállja a helyét, hiszen a rendőrség tagjai rendőrségi kutyáknak próbálnak nevet keresni, ezzel is ösztönözve a lakosság tagjait az együttműködésre.

\section{1. számú ábra: Névadás kutyakölyköknek}

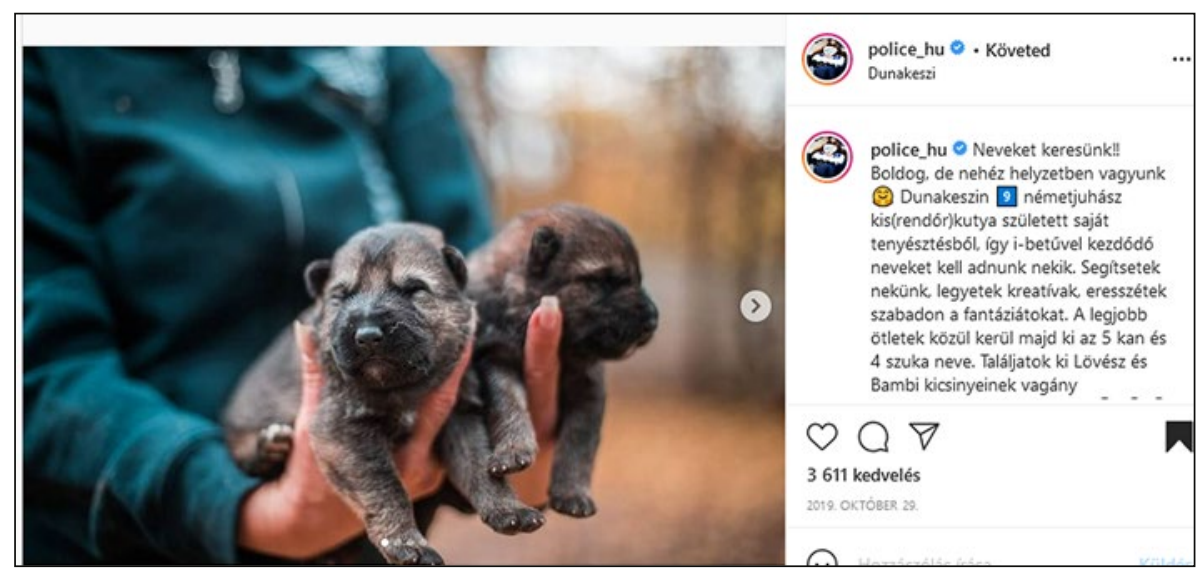

Forrás: URL6.

A bejegyzés létrehozójának ${ }^{4}$ elmondása szerint két fontos mozzanat nyilvánul meg ebben a posztban, ugyanis a fotók elkészüléséhez néhány alapvető feltételnek kellett megfelelni. Egyrészt szükséges volt a különbözö rendészeti szakterületekkel feltérképezni és kialakítani a megfelelő információs csatornákat, majd megtalálni azokat a szakembereket, akiktől a jelzés is érkezett a történet bemutatására. Így jutottak el a Rendőrségi Oktatási és Kiképző Központba,

3 A call-to-action (CTA) a marketing területén használatos fogalom, mely a közösségi média népszerüségével általánossá vált gyakorlat. Jelentése olyan tartalmat jelöl, amelynek célpontja az olvasó, a néző, a felhasználó, és egy adott cselekvés végrehajtására ösztönöz.

4 Az információk Boross Tamástól, a magyar rendőrség Instagram-oldalának egyik kezelőjétől származnak. A beszélgetés ideje: 2021.03. 10. 
Dunakeszire, ahol a kiskutyákról első kézből tudósítottak. Másrészt fontos alapelv a követők bevonása annak érdekében, hogy interakciót generáljanak, amellyel erősíthetik a militarizált szervezet és a civilek közti bizalmi kapcsolatot, amely egyik fő célja a rendőrség Instagram-oldalának. A közel ezer komment pedig azt mutatja, hogy az irány jó, hiszen az emberek fogékonyak a rendőrség által megosztott témákra, ha azok olyan történettel szólítják meg az oldal követőit, amelybe saját magukat helyezve azonosulni tudnak.

\section{A rendöri hivatás népszerüsitése - rendörlányok}

A bejegyzés dátuma 2019. február 26., a fényképen hat fiatal rendőrhölgy látható egyenruhában (2. számú ábra). A kép eredetileg a Zsaru Magazinban jelent meg, amelyet felhasználásra kértek az oldal kezelöi és posztolták. A bejegyzéshez több mint 5500 kedvelés és nagyjából 200 komment érkezett. A hölgyek keresztnévvel és arccal is vállalják az általuk választott foglalkozást, egyértelmüen kiemelik és elismerik a rendőri hivatás népszerüsítését, melyet nemcsak munkaként, hanem hivatásként definiálnak. Külön érdekesség a „család” szó használata a bejegyzés szövegében, amely egy metafora. A szervezetet a bejegyzés létrehozója a társadalmi élet legszorosabb kötelékéhez hasonlítja, melylyel egyik alapvető célja „az egy család vagyunk” érzés erősítése a hivatásos állomány körében.

\section{2. számú ábra: Rendőrhölgyek}

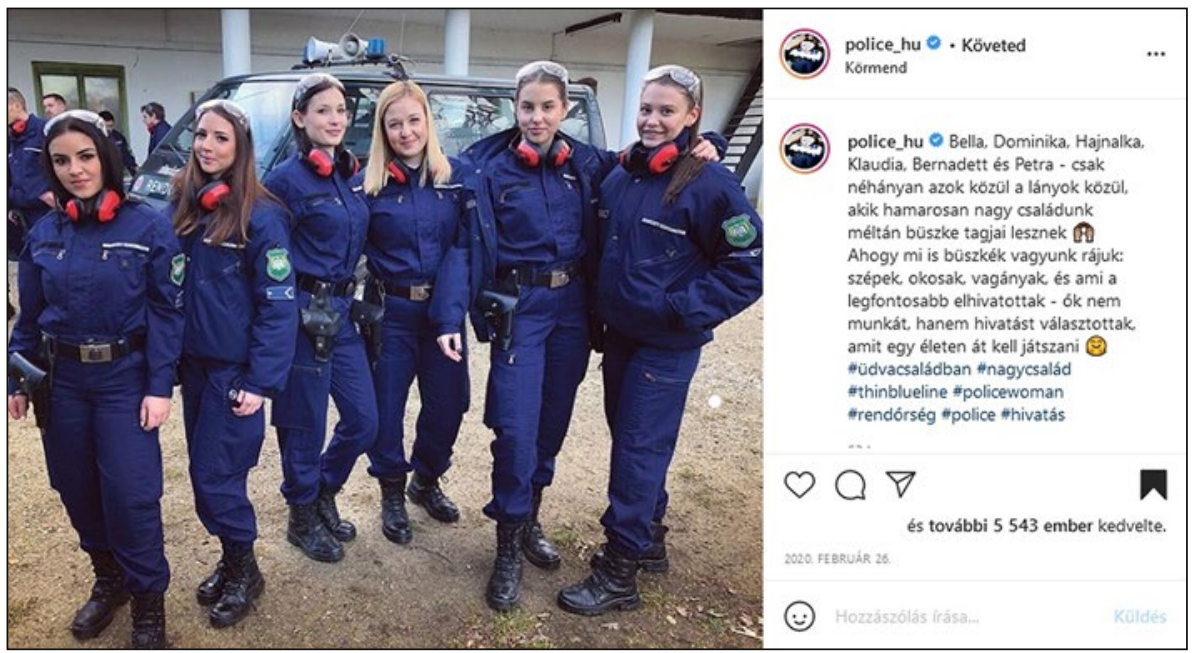

Forrás: URL7. 
Az „egy életen át kell játszani” sor pedig Hevesi Tamás: „,Ezt egy életen át kell játszani" címü dalára utal. Azaz a verbális és vizuális kommunikációt a felhasználó összekapcsolta a zene világával, azt feltételezve, hogy a felhasználók ismerik a dalt, és tudják, honnan származik az idézet. Az oldal kezelöjének elmondása alapján a legfontosabb tanulság az volt számukra, hogy rengeteg troll ${ }^{5}$ írt a bejegyzéshez, ami szigorú moderálást igényelt. Az pedig alapvető, hogy mindig kiállnak a kollégáik mellett, ahogyan itt is ez történt.

\section{Gál Kristóf, a rendörség szóvivöje}

A bejegyzés létrehozásának időpontja 2020. március 11., ami már a koronavírus magyarországi megjelenési időpontja után készült (3. számú ábra). Gál Kristóf az Operatív Törzs tagjaként az Instagramon való szereplést átmenetileg vagy sem, de abbahagyta, hiszen napi szintü, sokszor erőn felüli teljesítménye a közösségi oldalon való szereplést már nem tette lehetővé. Ennek ellenére az általa hirdetett naptár a beérkező kommentek száma alapján a vizsgált időszak egyik legnépszerübb bejegyzése volt. Személyes hírneve, elismertsége eddig sem volt kérdés, ezután azonban vitathatatlan.

\section{3. számú ábra: Gál Kristóf, az ORFK szóvivője}

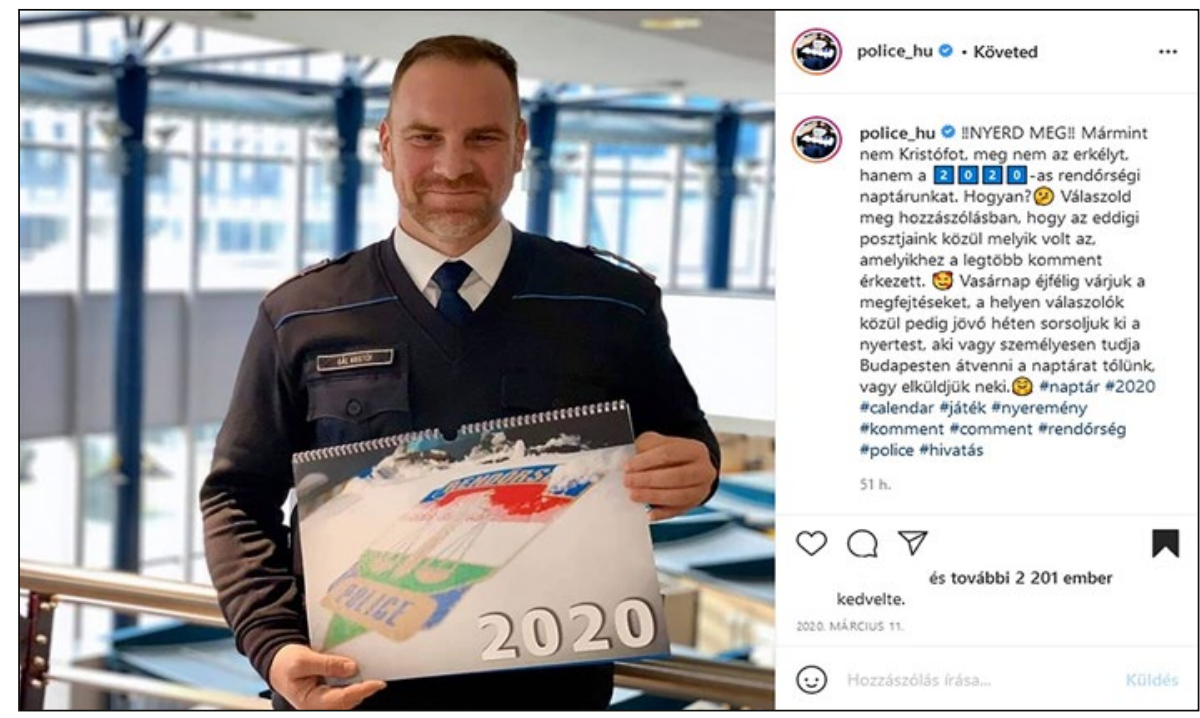

Forrás: URL8.

5 Az internetes szlengben olyan személyt jelöl, aki gúnyos, bántó, a témához nem illeszkedő megjegyzéseivel zaklat egy online közösséget. 
Az oldal kezelői Gál Kristóf szóvivő ismertségét korábban is igyekeztek kihasználni, ahogy teszik ezt jelenleg is, hiszen ezáltal az üzeneteik jobban célba érhetnek. Gál Kristóf rendőr alezredes, rendőrségi szóvivő népszerüsége mindenképpen párosul egy, a személyének szóló elismeréssel is, ami a kommentek tartalmából is megállapítható. Több esetben hasonlítják össze Győrfi Pállal, az Országos Mentőszolgálat szóvivőjével, és számos bejegyzésben gratulálnak neki ahhoz, hogy a rendőrség végre hiteles és a társadalom által is elfogadott rendőrt, és ezzel együtt példát tudott állítani a szervezet kommunikációjának élére. Ezzel igazolható az, hogy a szubjektivitás (az állampolgárok vélekedése) és a hitelesség (Gál Kristóf szakmai hozzáértése) hozzárendelhető a szervezet (rendőrség) népszerüségéhez.

\section{Online reputáció - kommentkiemelés}

A4. számú ábrát illetően már bizonyítottnak értékelhető az az állítás, hogy nemcsak a kedvelések, hanem a hozzászólások száma is, de még inkább azok minösége árulkodik arról, hogy a felhasználók mennyire tudtak azonosulni az adott témával és annak képi világával. A kép a magyar rendőrség Instagram-profiljának első éves történetében az egyik legsikeresebb bejegyzésének része, így a kommentfotó és kommentkiemelés sem véletlen.

4. számú ábra: Rendörlányok - kommentfotó, kommentkiemelés

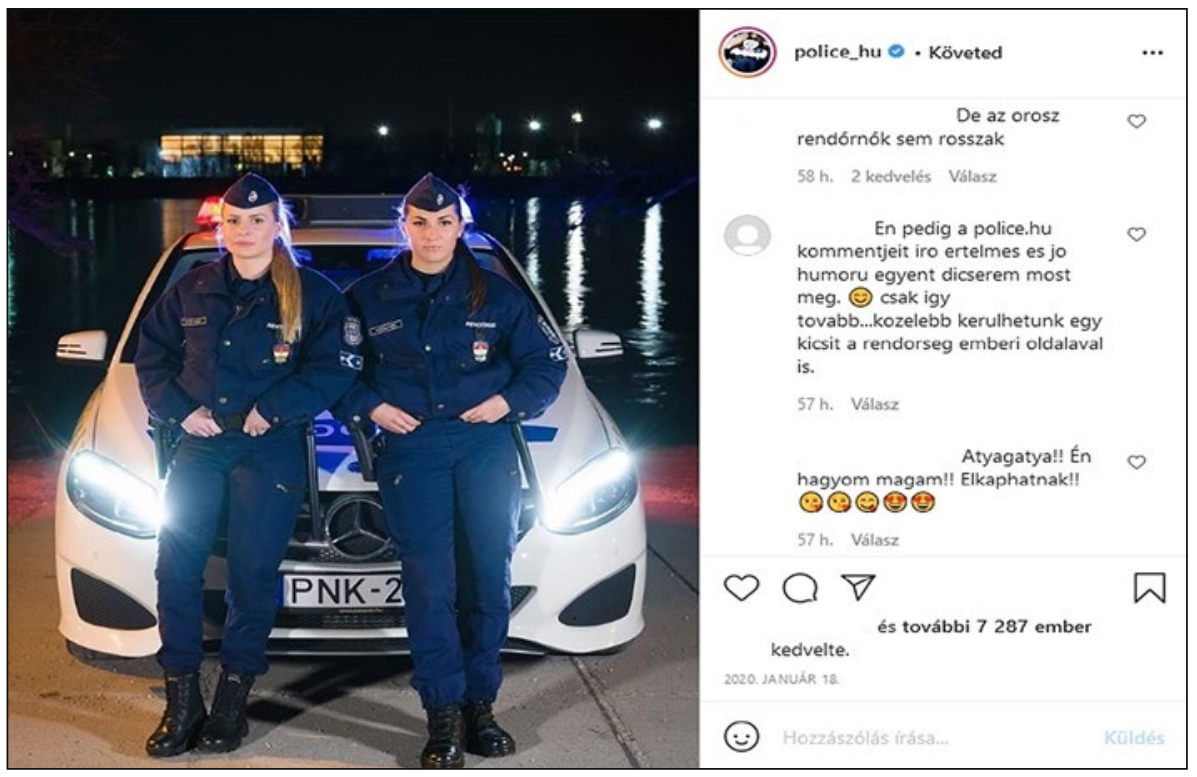

Forrás: URL9. 
Egy felhasználó, aki névvel és arccal vállalva írta a kommentjét: „Én pedig a police.hu kommentjeit iró értelmes és jó humorú egyént dicsérem mostmeg. (:) csak igy tovább ...közelebb kerülhetünk egy kicsit a rendörség emberi oldalával is."

A komment két releváns információval bír. Egyrészt a kommentszekciókat olvasva az első év (2019. július 3. - 2020. július 3.) alapján egyértelmű, hogy a lakosság tagjai értékelik azt a kommunikációs stílust, amit a police_hu oldalon látnak, és dicsérik az üzemeltetők kommunikációs stílusát. Az itt alkalmazott és nap mint nap tapasztalt humorról elmondható, hogy okos, intelligens, és habár az egyes helyzetekre való helyes reagálás az oldal követői, de akár általánosságban az állampolgárok számára a legtöbb esetben nehézséget okozna, de nem így az oldal kezelőinek. ${ }^{6}$

Másrészt az oldal vizsgált időszaka alapján látható, hogy a lakosság kezd hozzászokni a rendőrség jelenlétéhez ezen a felületen is (hasonlóan a 2016ban elindult Twitterhez). Természetesen nem egységes a vélemény, hiszen mint minden más esetben, itt is vannak olyanok, akik meglepődnek a szervezetnek a közösségi oldalon való közvetlen hangvételü és stílusú jelenlétén, a korábban tapasztalt hatalmi, sok esetben tekintélyelvü kommunikációs stílusú tartalombejegyzéseihez képest.

A távolságtartó stílus, a jogi és szakmai kifejezések túlzott használata, és a szakzsargon komplexitása egyébként az egész magyar rendőrségi kommunikációt mind a mai napig áthatja, pedig ezt már a kétezres évek elején nehezményezte a tisztképzésben oktató, a rendőri hivatalos írásbeli nyelvhasználatot nyelvi lektori minőségében is évtizedek óta enyhítő kommunikációs szakember, aki szerint a rendőrség kommunikációs stílusának „,mondatszerkesztésére-minden érthetöségi törekvés ellenére - a bonyolultság, a nehézkesség, a terjedelmesség, sőt terjengősség jellemzö. Megmutatkozik ez a feleslegesen hosszú, sokszorosan összetett vagy éppen a végtelenségig bövitett egyszerü mondatokban; a sok elemü jelzös szerkezetekben; az egyszerü szavak helyett a terjengös kifejezések, szószerkezetek alkalmazásában; a hivatalos izü kötöszavak, névutók használatában; az igei szerkezetekkel szemben a névszóiak túlsúlyában stb. [...] A rendvédelem területén a hivatalos stílus eröteljes jelenléte adja a stílus egyik gyakori és legnagyobb hibáját. Arról van szó, amikor az egyén hétköznapi nyelvhasználatára, annak minden szegmensére (szövegszerkesztésére, mondatalkotására, szóhasználatára, modorára) a hivatalos stílus jegyei átterjednek, vagy még szemléletesebb kifejezéssel rátelepszenek. Vagyis - sajnos - a hivatalos

6 Simon Edina Tünde r. föhadnagy és Boross Tamás rendvédelmi alkalmazott nevét meg kell említenünk a magyar rendőrség Instagram-profiljának kezelői között, habár a teljes tartalom számos ember munkájának eredménye. 
stílus, pontosabban a »hivataloskodás " fertözö az e stílust nap mint nap használókra nézve. Ez ellen kizárólag tudatosan, akaratlagosan lehet védekezni" (Molnár, 2002).

Mindez nem változtat azon a tényen, sőt megerősíti, hogy összességében a lakosság üdvözli a kedvezményezést, ami a kommentek számának növekedésével és minőségével érhető leginkább tetten.

\section{A hipotézisek igazolása}

Az első feltételezésünk, miszerint a police_hu oldalon létrehozott rendészeti digitális kommunikációs tartalmak átrendezik az egyén, a társadalom és a különböző szervezetek viszonyait és kapcsolatrendszerét, beigazolódott. Ezt bizonyítja az, hogy a magyar rendőrség Instagram-profilján zajló kommunikációs folyamatoknak köszönhető egyfajta átrendeződés, amely pozitív változást eredményezett a rendörségről alkotott kép és vélemény terén; ezen megállapítás a kutatott online felület adataira épül. Megállapíthatjuk, hogy az oldal tudatos használatával a rendészeti szervezet felismerte a lakosság tagjainak párbeszéd iránti igényét; legalábbis azokét, akiknek van online elérése, Instagram-fiókja, és kíváncsi, esetleg követi a rendőrség ezen felületét. A stratégia vizsgálata ennek a tanulmánynak még nem képezte részét, de az adott célcsoporttal történő kétoldalú, partneri kommunikáció teljes mértékben megvalósult a mintavétel időszakában. Azaz a magas színvonalú rendészeti digitális kommunikációs folyamatoknak köszönhetően nemcsak a különböző szervezetek (jelen esetben konkrétan a magyar rendőrség), hanem az egyén és a társadalom egy viszonylag jól körülhatárolható rétegének viszonya és kapcsolatrendszere is átrendeződni látszik. A későbbiekben kutatás tárgyát képezheti, hogy a police_hu oldal követőivel való megfelelő és rendszeres partneri 1563

kommunikációnak milyen hatásai vannak (lehetnének) a közbiztonságra. A Police Café technika (Molnár \& Uricska, 2018) alkalmazása kapcsán erről írt többek között Molnár és Tamási: „A módszer egyébként kiváló prevenciós eszköz is, hiszen ahol rendszeres és módszeres a párbeszéd a civilek és a rendészeti szakemberek között, ott kiszámithatóan kevesebb lesz a probléma is" (Molnár \& Tamási, 2019).

Második feltételezésünk az volt, hogy az azonnali válaszadás lehetőségeit kihasználva a magyar rendőrség a lakosság közvetlen elérésére, bizalomépítésre, partneri viszony kialakítására törekszik, ezáltal a szervezet megítélése pozitív irányban változott, amelynek a visszajelzésekben (komment, emotikon) meg kell jelennie. A hipotézis második részének bizonyítására több száz 
komment áll rendelkezésre, azaz hipotézisünk igazolást nyert azzal a kitétellel, hogy a police_hu moderálási elveihez (URL10) igazodva az Instagramon egy átlagos állampolgár vagy egy kutató az eltávolított kommenteket nem láthatja. A későbbiekben azonban feltétlenül értékes lehet az ezekhez való kutatási célú hozzájutás, hiszen a szervezetről szóló negatív vélemények legalább annyira tanulságosak - nemcsak a kutató, hanem az általa nyújtott kép segítségével a szervezet kommunikációjának irányairól döntést hozók számára is -, mint a pozitívak. Érdemes feloldani azonban azt a félreértést, amely szerint a negatív véleményt moderálják a közösségi médiában. Ha valaki a negatív véleményét kulturáltan fogalmazza meg, nem személyeskedő és sértő stílusban teszi, illetve nem politizál a kommentben, akkor az a tartalom nem kerül moderálásra. A véleménynyilvánítás szabadsága a közösségi médiában is létezik, a kérdés az, hogyan él vele a felhasználó.

A vizsgált időszak alapján tehát kijelenthető, hogy az oldal tartalma a közösség tagjait nagymértékben szolgálja. A vizuális és verbális tartalmak, vagyis a rendészeti digitális diskurzus minőségével és a közvetlenebb nyelvhasználati stílusréteg, azaz a rendészeti digilektus alkalmazásával a harmadik feltételezés is bizonyítást nyert. A rendőrség hagyományos csatornáihoz (például televízió, www.police.hu) képest az oldalon létezik egy kötetlenebb stílus és nyelvváltozat, a rendészeti digilektus, amely leginkább a vizsgált bejegyzések hangvételéből, szóhasználatából érhető tetten.

\section{Összegzés}

»Edina, Tamás, elismerésre méltó az a tevékenység, amit ezen az oldalon Ti nap mint nap véghez visztek! Az a rengeteg munka, amivel ezt az arculatot kialakitottátok és fenntartjátok, tiszteletet érdemel! Ti tettétek egyedivé, különlegessé a magyar rendörség nevét, a „police hu” szinte már egy brand, egy márkanév itt a neten, s természetesen a tartalom, amit takar, a hivatás, az életforma, a rendeltetése, minden funkció, ami hozzá köthetö, és amilyen szinesnek és érdekesnek bemutattátok, illetve amilyenné Ti varázsoltátok! Edina, Tamás, naggyá tett Titeket ez a csodálatos feladat! Profik vagytok! « (URL11). A kutatási eredmények alapján megállapítható, hogy az Instagramon az egyoldalú, úgynevezett távolságtartó, hivatalos, hatalmi kommunikációt felváltja egy kétoldalú, partneri kommunikáció. A kétoldalú kommunikáció lehetőségének helyes alkalmazása, és a lakosság bizalmának megnyerése érdekében a rendészeti digilektus kerül előtérbe. Ez egy személyesebb, kötetlenebb nyelvváltozatot határoz meg, ami a rendészeti szaknyelv új változata is egyben. Az oldal kezelői jól érzékelik 
a rendészeti szaknyelv e stílusát, amely a lehető legszélesebb befogadói réteg számára világos, érthető, ezáltal hozzájárul ahhoz, hogy a társadalom számára kialakítson egy olyan képet a rendőrségről, melynek alapja a bizalom, illetve a rendörség és a polgári lakosság közti kommunikációs távolság(tartás) csökkenését eredményezi.

A kutatás a továbbiakban kiterjeszthető a rendőrség egyéb online platformjainak vizsgálatára, a polgári lakosság és hivatásos állomány kérdőíves vizsgálatára, illetve a nemzetközi jó gyakorlatok feltérképezésére, azok absztrahálására is. A bizalom témájának két tanulmányt is szentelt Kozáry Andrea, aki a rendőrség társadalomban elfoglalt helyének, presztízsének elsősorban politológiai-szociológiai aspektusait kutatta ugyan, de ennek részeként a kommunikáció jelentőségével is tisztában volt. Gondolatai és egy másik írásának címében idézett szólás - „A bizalom gyalog jön és lóháton távozik” - itt teljes egészében helytálló (Kozáry, 2018; 2019).

A bizalom kialakításához a rendőrség a közösségi oldalon képviselt attitüdváltással (rendészeti digilektus alkalmazása) megtette az első lépéseket, amelyet az oldal követői többségi arányban elismeréssel fogadtak. Mindezt az is igazolja, hogy a kézirat leadásának napjaiban érte el az oldal a több mint másfél éves jelenlétet, és az ezredik bejegyzést, ami azt bizonyítja, hogy ennek a tevékenységnek a fenntartása időigényes, illetve folyamatos, aktív jelenlétet kíván. Ez a fajta közösségépítés azonban nemcsak mennyiségi, hanem minőségi folyamat, amely törékeny is egyben.

\section{Felhasznált irodalom}

Aristovnik, A., Keržič, D., Ravšelj, D., Tomaževič, N. \& Umek, L. (2020). Impacts of the COVID-19 Pandemic on Life of Higher Education Students: A Global Perspective”. Sustainability, 12(20), 8438-8471. https://doi.org/10.3390/su12208438

Barnucz N. \& Uricska E. (2020a). Innovatív nyelvtanulási módszerek és módszertan a rendészeti szaknyelv vizsgálatában. Új Pedagógiai Szemle, 70(9-10), 53-63.

Barnucz N. \& Uricska E. (2020b). Kiterjesztett valóság és közösségi oldalak alkalmazása a nyelvoktatásban különös tekintettel a rendészeti szaknyelvre. Educatio, 29(4), 644-652. https://doi. org/10.1556/2063.29.2020.4.9

Benczik V. (2015). A médium és az üzenet. Könyv és Nevelés, 12(1), 5-24.

Beduschi, A. (2019). Digital identity: Contemporary challenges for data protection, privacy and non-discrimination rights. Big Data \& Society, 6(2), 1-6. https://doi.org/10.1177/ 2053951719855091

Borszéki J. (2019). E-learning anyagok használata az angol rendészeti szakmai nyelv oktatásá- 
ban, Rendészeti Tanulmányok, 2(3), 115-149.

Boyd, D. M. \& Ellison, N. B. (2007). Social Network Sites: Definition, History, and Scholarship. Journal of Computer-Mediated Communication, 13(1), 210-230. https://doi.org/10.1111/ j.1083-6101.2007.00393.x

Carver, T. (2004). Diskurzuselemzés és a „nyelvi fordulat”. Politikatudományi Szemle, 13(4), 143-148.

Colbran, M. P. (2020). Policing, social media and the new media landscape: can the police and the traditional media ever successfully bypass each other? Policing and Society, 30(3), 295309. https://doi.org/10.1080/10439463.2018.1532426

Farkas J. \& Horváth J. (2020). Szervezeti kultúrák és kutatásuk. Ludovika Kiadó.

Farkas J., Sallai J. \& Krauzer E. (2020a). The History of Law Enforcement Culture in Hungary. Belügyi Szemle, 68(2), 37-52.

Farkas J., Sallai J. \& Krauzer E. (2020b). The organisational culture of the police force. Internal Security, 12(1), 77-84.

Hall, J. A. (2019). How many hours does it take to make a friend? Journal of Social and Personal Relationships, 36(4), 1278-1296. https://doi.org/10.1177/0265407518761225

Heravi, B. R. \& Harrower, N. (2016). Twitter journalism in Ireland: sourcing and trust in the age of social media. Information, Communication \& Society, 19(9), 1194-1213. https://doi.or g/10.1080/1369118X.2016.1187649

Kozáry A. (2018). „A bizalom gyalog jön és lóháton távozik.” A multikulturális társadalom legújabb kihívásai: a rendőrség és a bizalomépítés. In Dobák I. \& Hautzinger Z. (Szerk.), Szakmaiság, szerénység, szorgalom. Ünnepi kötet a 65 éves Boda József tiszteletére (pp. 415-423). Dialóg Campus Kiadó.

Kozáry A. (2019). Töprengések a biztonságról és a rendőrségbe vetett bizalomról. In Hautzinger Z. \& Gaál Gy. (Szerk.), Gondolatok a rendészettudományról. Írások a Magyar Rendészettudományi Társaság megalapításának tizenötödik évfordulója alkalmából (pp. 203-208). Magyar Rendészettudományi Társaság.

Less F. (2015). A közösségi hálózatok és a közösségi rendőrség kapcsolata (Mi keresni valója van a rendőrségnek a Facebookon?). Nemzetbiztonsági Szemle, 3(1), 26-51.

Markos-Kujbus, É. \& Gáti, M. (2012). A közösségi média, mint online stratégiai eszköz. In Piskóti I. (Szerk.), „Coopetition”: verseny és együttmüködés a marketingben (pp. 1-10). Konferenciakiadvány.

McDermot, M. (2018). Digital footprints: Creation, implication, and higher education. FDLA Journal, 3(11), 1-6.

Micheli, M., Lutz, C. \& Büchi, M. (2018). Digital Footprints: An Emerging Dimension of Digital Inequality. Journal of Information Communication and Ethics in Society 16(3), 242-251. http://doi.org/10.1108/JICES-02-2018-0014

Molnár K. (2002). Stílusrétegek és müfajok a rendvédelmi kommunikációban. Belügyi Szemle, 50(11-12), 238-247. 
Molnár K. (2018). Rendészeti kommunikáció - a média tükrében. Kézikönyv és szemelvénygyüjtemény a rendészeti szakújságíró szakirányú továbbképzési szak hallgatóinak. Dialóg Campus Kiadó.

Molnár K. \& Tamási Zs. (2019). A rendörség közösséggel való kapcsolatának javítási lehetőségei. Belügyi Szemle, 67(4), 35-56.

Molnár, K. \& Uricska, E. (2018). The Police Café - An Efficient method for improving the dialogues between the Police and the Community. In Nogala, D., Görgen, T., Jurczak, J., Meszaros, B., Neyroud, Pais, L.G. \& Vegrichtova, B. (Eds.), European Law Enforcement Research Bulletin, Special Conference Edition 4, (pp. 221-226). CEPOL.

Pirzada, K. \& Khan, F. N. (2013). Measuring Relationship between Digital Skills and Employability. European Journal of Business and Management, 5(24), 124-133.

Shearer, E., Barthel, M., Gottfried, J. \& Mitchell, A. (2015). The Evolving Role of News on Twitter and Facebook. Pew Research Center.

Stenger, T. (2014). Social Media and Online Reputation Management as Practice: First Steps Towards Social CRM? International Journal of Technology and Human Interaction, 10(4), 49-64. http://dx.doi.org/10.4018/ijthi.2014100104

Uricska, E. (2020a). Proper interactive communication of the police as a (n e-) trust-building strategy. Introducing the term policing digilect. Kosice Security Revue, 10(2), 185-195.

Uricska E. (2020b). Közösségi rendészet - közösségi média. Elméleti háttér és a rendészeti digilektus fogalmának bevezetése. Magyar Rendészet, 20(2), 153-168.

Vályi G. (2007). Közösségek hálózati kommunikációja. Szociológiai Szemle, 14(4), 47-60.

Veszelszki, Á. (2017a). Digilect. The Impact of Infocommunication Technology on Language. De Gruyter Saur.

Veszelszki Á. (2017b). Netnyelvészet. Bevezetés az internet nyelvhasználatába. L'Harmattan Kiadó. Yonetani, R., Kitani, K. M. \& Sato, Y. (2018). Ego-Surfing: Person Localization in First-Person Videos Using Ego-Motion Signatures. Journal Article, IEEE Transactions on Pattern Analysis and Machine Intelligence, 40(11), 2749-2761. http://doi.org/10.1109/TPAMI.2017.2771767

\section{A cikkben található online hivatkozások}

URL1: 56\% of Internet Users Have Searched for Themselves Online. https://mashable.com/archive/google-yourself

URL2: Gál Kristóf az Instagram kommunikációjáról - videó. https://www.instagram.com/p/ CB4_-6aBo4L/

URL3: Jankovics Péter szinésszel készült videó a 112 hívószámról. https://www.instagram. com/p/Bzctl_zhvHH/

URL4: Gál Kristóf és Hodász András atya. https://www.instagram.com/p/B5sNttKho0Y/

URL5: Új intézkedések a járvány ellen. https://www.instagram.com/p/CFO3ym4BgEE/ 
URL6: Névadás kutyakölyköknek. https:/www.instagram.com/p/B4M2XD1BPcB/

URL7: Rendörhölgyek. https://www.instagram.com/p/B9CxjKnhXDF/

URL8: Gál Kristóf, az ORFK szóvivője. https://www.instagram.com/p/B9my1sZhxCk/

URL9: Rendörlányok - kommentfotó, kommentkiemelés. https://www.instagram.com/p/B7eVB$47 \mathrm{hUON} /$

URL10: Instagram, police_hu, A moderációról.

https://www.instagram.com/stories/highlights/17880457390558100/

URL11: Lakossági komment a magyar rendörség profiján. https://www.instagram.com/p/ CLuhWKeB-3U/

\section{Alkalmazott jogszabályok}

1994. évi XXXIV. törvény a Rendőrségről

30/2011. (IX. 22.) BM rendelet a rendőrség szolgálati szabályzatáról

1536/2016. (X. 13.) Korm. határozat a köznevelési, a szakképzési, a felsőoktatási és a felnőttképzési rendszer digitális átalakításáról és Magyarország Digitális Oktatási Stratégiájáról

Az országos rendőrfőkkapitány 41/2019. (XII. 13.) ORFK utasítása a közösségi média és az internetes felületek rendőrségi használatáról

\section{A cikk APA szabály szerinti hivatkozása}

Uricska E. (2021). Online reputációmenedzsment a police_hu Instagram-profilján. Belügyi Szemle, 69(9), 1529-1547. https://doi.org/10.38146/BSZ.2021.9.2 